\title{
METAMORPHIC ZONING IN THE SERIDÓ REGION, NORTHEASTERN BRAZIL*
}

\author{
AROLDO A. DE MELLO and ZENAIDE F. DE MELLO**
}

ABSTRACT The metamorphic belt recognized in the Serido region, Rio Grande do Norte State, northeastern Brazil, is made up of metamorphosed sediments of Precambrian age which are considered to belong to the low-pressure type.

The metamorphic pelitic rocks are divided in two parallel zones with a northeast direction, formed in the greenschist and cordierite-amphibolite facies, respectively.

The metamorphic gradient rises from west to east, the progressive mineralogical variation being represented by the appearence, in order of increasing metamorphic grade, of the following minerals: chlorite, muscovite, biotite, garnet, staurolite, andalusite, cordierite, sillimanite.

The synkinematic phase characterized by granitic rocks of 550 m.y. was succeeded by numerous intrusions of pegmatites, some of them showing mineralizations.

Among the metamorphic minerals cordierite is the most important and characteristic of the Seridó belt.

RESUMO O cinturão metamórfico individualizado na região do Alto Seridó, Estado do Rio Grande do Norte, compreende uma série de rochas cristalofilianas de idade pré-cambriana, cujo metamorfismo regional dínamotermal enquadra-se no tipo de pressão baixa.

$\mathrm{O}$ estudo das rochas pelíticas metamorfoseadas permite a individualização das fácies de xistos verdes e cordierita-anfibolito, dispostas segundo faixas aproximadamente paralelas de direção nordeste.

As associações minerais e o estudo de campo mostram que o gradiente metamórfico cresce dé oeste para leste, sendo representado pela seguinte sucessão mineral progressiva: clorita, moscovita, biotita, granada, estaurolita, andaluzita, cordierita, sillimanita.

A fase sincinemática, caracterizada pelas rochas graníticas de idade 550 m.a., foi sucedida por intrusões de numerosos pegmatitos graníticos, freqüentemente mineralizados, comuns nas partes de metamorfismo mais alto.

INTRODUCTION This paper describes the progressive regional dynamothermal metamorphism in the Seridó region, northeastern Brazil. The study was carried out in a part of Seridó belt, between the parallels $6^{\circ} 00^{\prime}$ and $7^{\circ} 00^{\prime} \mathrm{S}$. and the meridians $36^{\circ} 00^{\prime}$ and $37^{\circ} 00^{\prime}$ W.Gr. (Fig. 1).

Considering its economic importance, this area was extensively investigated by many authors but for the first time the concept of metamorphic facies series is applied.

It is probable that the individualization of the Seridó belt with a well developed and exposed facies series opens an important field of study in crystalline rocks of Precambrian age in Brazil.

The rocks collected by the authors have in part been investigated at the Division of Geology of Sudene and at the Department of Mineralogy and Petrology of the Geo-Science Institute of the Federal University of Pernambuco at Recife.

Metamorphosed pelitic rocks were intensively studied by field and petrographic methods as the base for the present work.

*With the aid of Conselho Nacional de Pesquisas

**Chief geologist of Laboratório de Mineralogia e Petrografia. Divisão de Geologia, Sudene 


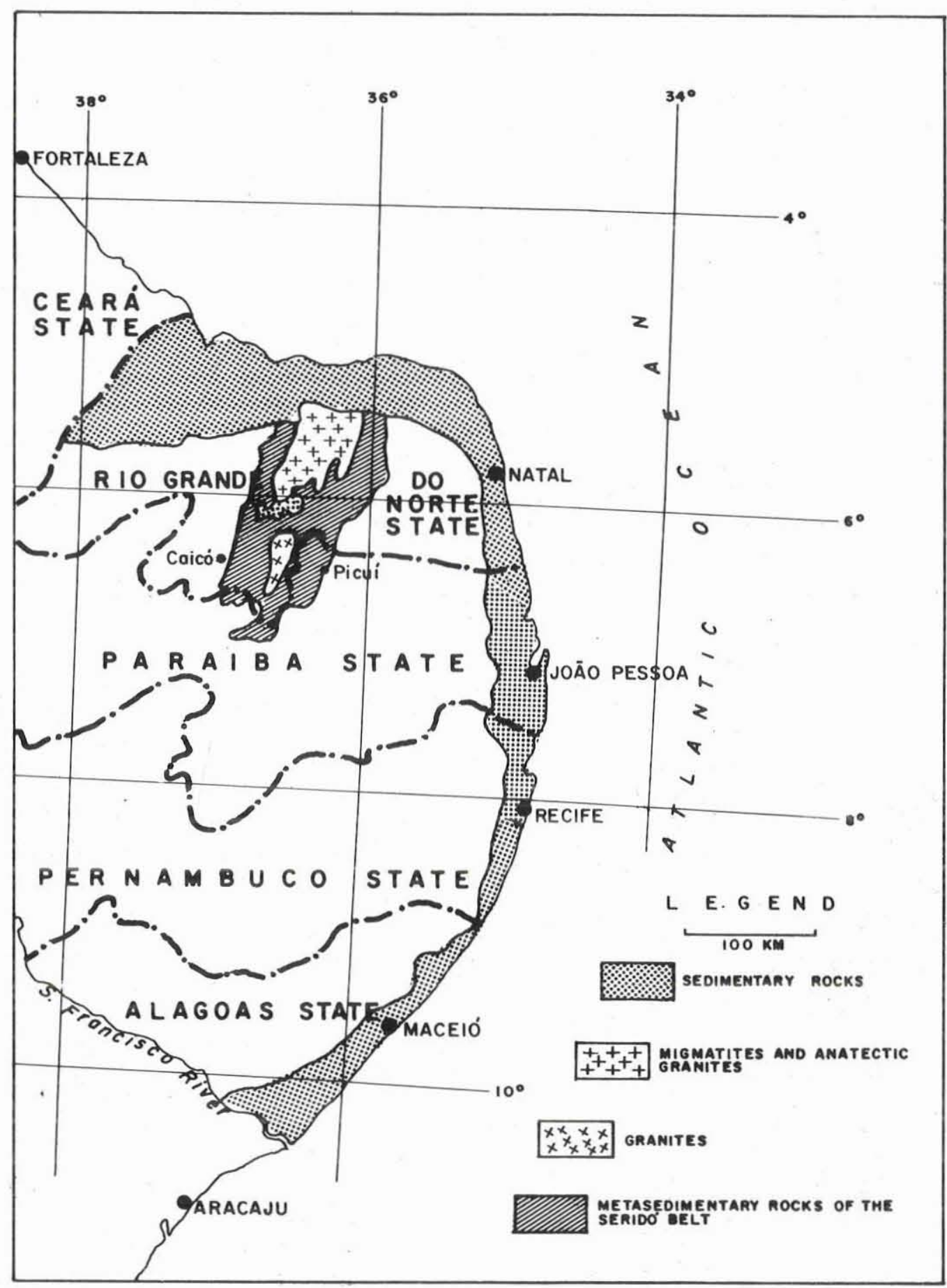

Figure 1 - Situation of the Seridó metamorfic belt 
Geologic setting The crystalline area of the Brazilian northeastern states (Ceará, Rio Grande do Norte and Paraíba), has been studied since the time of Crandall (1910) who distinguished a metasedimentary series (Ceará series composed by micaschists, limestones and quartzites) from a "Fundamental complex" composed by gneisses.

The age of the "Ceará Series" and the "Fundamental complex" was considered by Moraes (1924) as Algonkian and Archean, respectively.

The Ceará Series appears in the papers of Moraes (1938), Rolff (1945) and Chaves (1947) with the following stratigraphy and chronological sequence:

3) an upper clastic sequence (micaschists);

2) an intermediate sequence of precipitation (marble and tactites);

1) a lower clastic sequence (quartzites and metaconglomerates).

It is seems that, despite the name, the "Ceará series" as it was defined, embraces a sequence of metasedimentary rocks occurring exactly in the zone considered in this work as belonging to the "Serido belt" situated chiefly in the Rio Grande do Norte State and part of the Paraíba State.

The sequence of metamorphic rocks of the "Ceara series" was extended by Meunier (1964) who divided this series in two complexes. To the upper complex belong the sequences 2 and 3 mentioned above, whereas the lower complex called "Caicó complex" comprises the original quartzites of the "Ceará series" in association with crystalline limestone, biotite-gneiss and migmatites.

Medeiros Ferreira (1967) followed the same division of the "Ceara series" established by Meunier (op. cit.) but considered the two Complexes (Seridó Complex, upper and Caicó Complex, lower) limited by the quartzites of the sequence 1 cited above.

All the crystalline rocks of northeastern Brazil (Ceará, Rio Grande do Norte, Paraíba and Pernambuco States) are related to the "Caririan foldings" of Almeida (1967) and considered to belong to the Cariri orogenic belt (Cordani et al., 1967).

Another term applied to the crystalline area in NE Brazil "the Borborema belt" was introduced by Ebert (1970). To this tectonic element whose limits are not defined, this author considered three major groups based on unconformities:

\section{Seridó \\ Gaicó Upper Precambrian \\ Săo Vicente Middle Precambrian}

Based on metamorphic studies the authors of this paper are inclined to consider the "Ceara series" in its original definition. Considering that the metamorphic gradient in the studied area increases from west to east and applying Miyashiro's working hypothesis, it is probable that these series belong to a metamorphic belt whose development would have taken place in a sialic mass, in relatively shallow depressions.

Whether the rocks belonging to the Caicó complex form another metamorphic belt or if it corresponds to the basement (Fundamental Complex of Crandall) is an important question to solve.

Considering that the pelitic rocks show mineral assemblages of high grade towards east, it is more convincing that the migmatites and granites related to "Serido belt" are localized in the Santa Cruz rather than in the Caico quadrangle as envisaged by many others.

The Serid6 metamorphic series GENERAL STATEMENT This type of metamorphic facies series is characterized by the mineral assemblage common to the facies series of the andalusite-sillimanite type (Miyashiro, 1961). 
The study of Seridó schist in the area considered as belonging to the Serido belt revealed that the rocks are distributed in two zones comprising the greenschist and cordierite-amphibolite facies (Mello and Mello, 1972).

The recognition of this type of metamorphism in the Serido region was made for the first time by Mello and Mello (1971) based on the high grade assemblages found in the Seridó schist.

This facies series is very similar to the one of Abukuma-type, studied by Miyashiro (op. cit.) in the Abukuma-Ryoke belt, Japan.

The mineralogical difference between the Abukuma-type and the Serido-type metamorphism is that in the latter type, staurolite is present at the beginning of the amphibolite facies (called cordierite-amphibolite facies in this paper).

In the Seridó-type staurolite is found with quartz + biotite or with cordierite + + almandine + biotite. The assemblage staurolite + cordierite + andalusite was not found as in other facies series similar to the Abukuma-type (Buchan-type and Bosost-type) as stated by Winkler (1965).

The significance of staurolite in these types of facies series similar to Abukuma is not clear. Winkler (op. cit.) states that the absence of staurolite in the Abukuma area seems to be due to a lack of appropriate bulk composition. Ganguly (1972) based on experimental data says that the limits of P-T conditions over which staurolite and cordierite may coexist in natural assemblages is restricted, almost entirely within the field of andalusite, between $500-700^{\circ} \mathrm{C}$, and 2-6 kbars, thus defining the range of $\mathrm{P}-\mathrm{T}$ conditions for the "low-pressure intermediate facies series of the Buchan-type".

The pelitic rocks of the Abukuma Plateau, Japan, contain K-feldspar, sillimanite, and cordierite in the high-grade zone and andalusite with muscovite in the middle-grade zone of the amphibolite facies (Miyashiro, 1961). According to the same author andalusite starts to crystallize at the beginning of the middle-zone and cordierite in the middle of the same zone.

Hietanen (1967) considering the various assemblages of the Abukuma, places the metamorphism common in Japan at a pressure near the point of intersection of the andalusite-sillimanite boundary with the muscovite-K-feldspar curve, in a lower pressure field than the Buchan-type. This is in accordance with Miyashiro (op. cit.), who based his conclusion on the absence of staurolite in the Japan type.

At present there is general agreement considering three types of facies series: low intermediate - and high pressures. In this way the Seridó-type belongs to the first one (low pressure).

Based on field and petrographic investigations the present authors concluded that the metamorphism in the Seridó belt has a zonal succession whose order of appearance is as follows: chlorite, biotite, garnet, staurolite, andalusite, cordierite, sillimanite.

In the lower grade of this metamorphism (the greenschist facies group) chlorite-biotite-garnet are characteristic minerals in association with quartz \pm plagioclase.

In the higher grade (amphibolite facies group) staurolite-andalusite-cordierite-sillimanite are the most critical and important metamorphic minerals of the pelitic rocks (see Fig. 2).

PETROGRAPHY The rocks of the Serido belt are dominantly quartzites, and crystalline limestones generally associated with tactites and schists.

This section deals only with the schists of the studied area, considered as a result of pelitic assemblages metamorphosed under the conditions of the low-pressure facies series. 


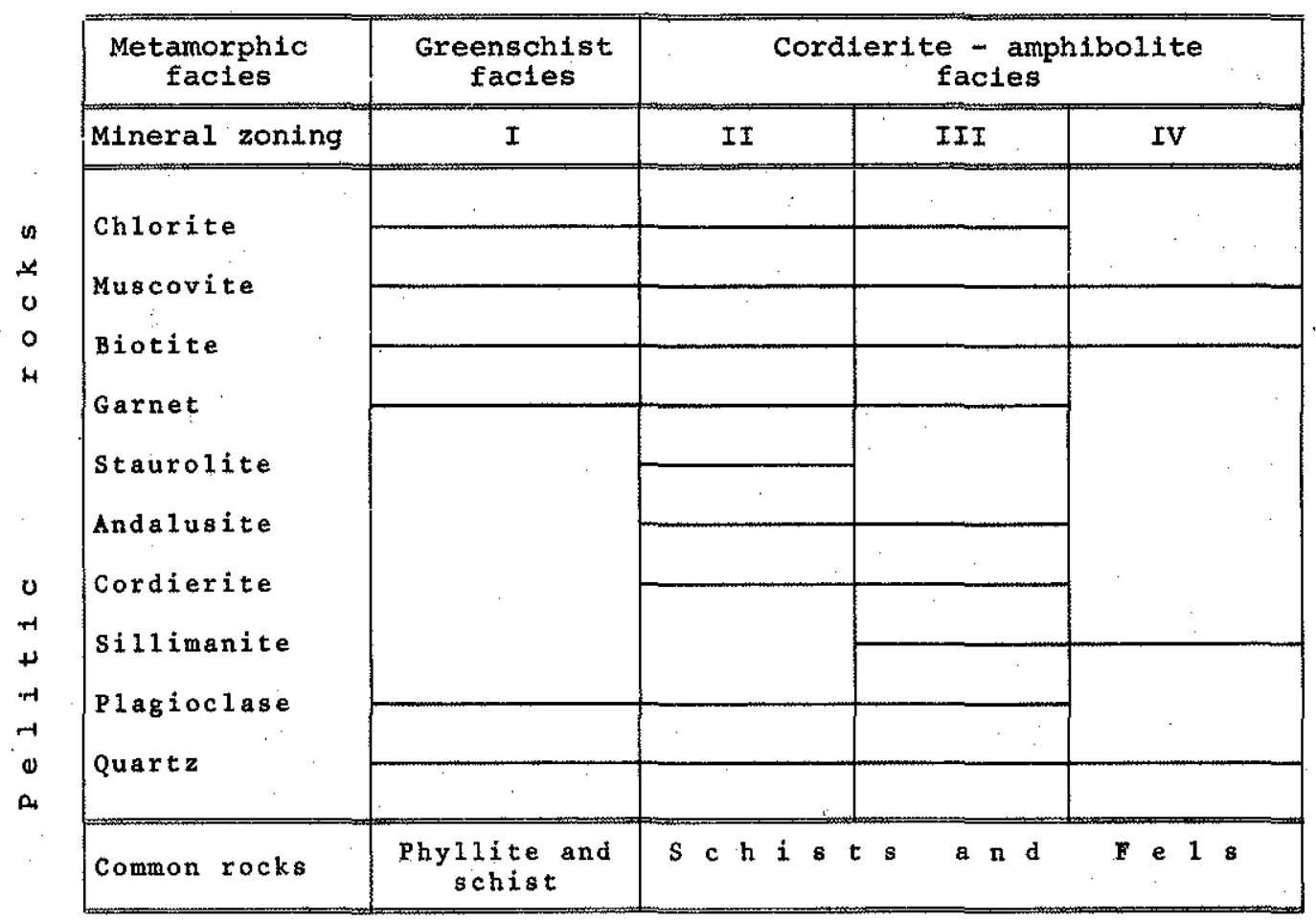

Figure 2 - Progressive mineralogical variation in regional metamorphism of Seridó region, Northeast Brazil

Low-grade assemblages The rocks of these assemblages are phyllites and schists. Megascopically, phyllites are typified by well developed cleavage crossing the bedding. They are light-green or grey in colour, and considered to have formed in the greenschist metamorphic facies conditions.

The phyllites change gradually to schists, rocks in which the mica flakes are visible to the naked eye.

The difference between the schists of the greenschist and those of the cordierite-amphibolite facies in the Serido belt is recognized by the presence in the latter of staurolite, andalusite, or cordierite, considering the position of the rocks in the field and the metamorphic gradient which increases from west to east.

High-grade assemblages The schists of this zone are essentially characterized by the presence of one or more of the following metamorphic minerals: staurolite, andalusite, cordierite and sillimanite. Among these cordierite is the most abundant and widespread. Frequently the presence of this mineral is so great and the schist is so hard that the name cordieritemfels is well applied (see Fig. 3).

The schists belonging to this grade are considered to be formed in the conditions of the amphibolite metamorphic facies. Particularly for this type of metamorphism and bulk composition this facies is called cordierite-amphibolite as suggested by Winkler (1965).

The mineralogical aspects of these rocks are shown in Figs. 4-7.

MINERALOGY Chlorite In the lower-grade rocks (phyllites) chlorite is the most important form of sheet silicate. The flaky crystals show greenish pleochroism. In the 
Table I - Modal analyses of the more common pelitic rocks of the Serido metamorphic belt

\begin{tabular}{|c|c|c|c|c|c|c|c|c|c|c|c|}
\hline & (1) & (2) & (3) & (4) & (5) & (6) & (7) & (8) & (9) & $(10)$ & (11) \\
\hline Chlori & 7.9 & 1.6 & 0.7 & 1.2 & 1.5 & 0.9 & 1.0 & 0.9 & 0.6 & - & - \\
\hline Muscovite & 3. & - & & - & & & 0.6 & - & 1.4 & - & 1.4 \\
\hline Biotite & 33.8 & 36.0 & 15.3 & 26.1 & 45.9 & 16.9 & 41.0 & 34.3 & 11.6 & 22.9 & 29.3 \\
\hline Garnet & - & 1.0 & - & 0.5 & 0.1 & 1.0 & 0.9 & 0.2 & - & 0.3 & - \\
\hline Staurolite & - & - & - & - & 5.9 & - & - & - & - & - & - \\
\hline Andalusite & - & - & 1.0 & 20.0 & - & - & - & - & - & $-m$ & - \\
\hline Cord & - & - & 34.9 & 21.6 & - & 56.3 & 27.0 & 2.1 & 44.8 & 24.0 & - \\
\hline Sillimanite & - & $-m$ & $m$ & - & - & - & $-m$ & - & - & - & 31.4 \\
\hline Plagioclase & 4.6 & 2.0 & - & - & - & 1.1 & 7.6 & 5.2 & 2.0 & 2.1 & - \\
\hline Quartz & 47.8 & 59.0 & 42.0 & 26.4 & 41.2 & 17.0 & 21.3 & 56.6 & 35.0 & 49.7 & 37.0 \\
\hline Pinite & - & - & 1 & - & - & - & - & - & - & 0.3 & - \\
\hline Tourmaline & 0.4 & - & 0.2 & 0.5 & - & 0.3 & - & 0.1 & 0.2 & - & - \\
\hline Apatite & 1.1 & - & 0.6 & 1.2 & - & 0.7 & 0.3 & 0.1 & - & 0.5 & 0.6 \\
\hline \multirow[t]{2}{*}{ Opac } & 1.3 & 0.4 & 1.2 & 1.4 & 0.8 & 2.9 & 0.3 & 0.5 & 4.4 & 0.2 & 0.3 \\
\hline & 100.0 & 100.0 & 100.0 & 100.0 & 100.0 & 100.0 & 100.0 & 100.0 & 100.0 & 100.0 & 100.0 \\
\hline
\end{tabular}

(1) Road Jardim do Seridó.Caicó villages; (2) Cruzeta village; (3) W. Carnaúba dos Dantas village; (4) road Currais Novos-São Vicente villages; (5) half-way Acari-Cruzeta villages; (6) Parelhas village; (7) Equador village; (8) road Currais Novos -São Vicente villages; (9) road Parelhas -Jardim do Seridó villages; (10) N. Acari village; (11) near "Serra dos Quintos". Samples 1 and 2 belong to the greenschist facies; the others ones to the cordierite-amphibolite facies

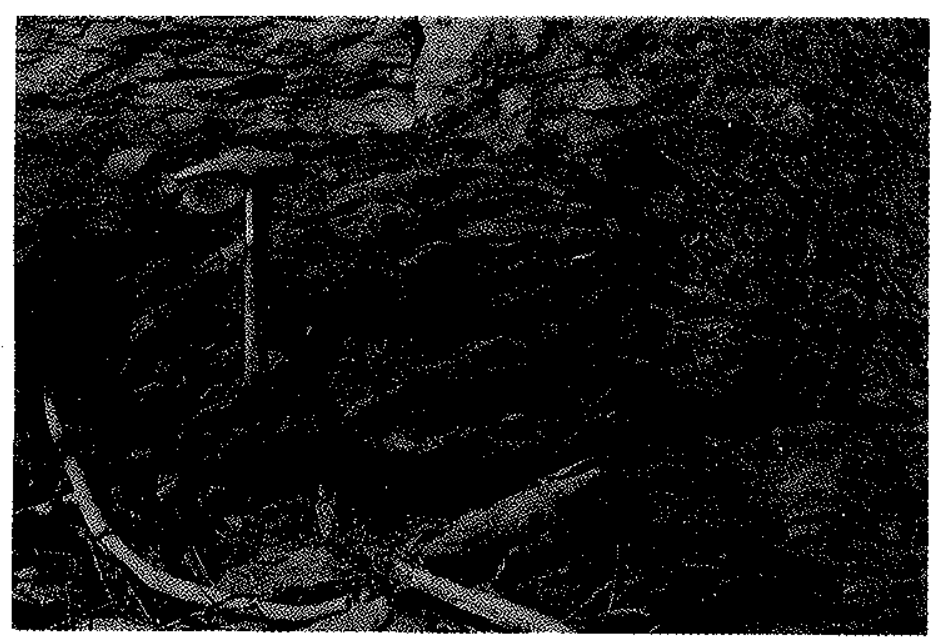

Figure $3-$. Cordierite showing nodular aspects exceptionally well developed in metamor. phosed pelitic rocks. Road Parelhas - Jardim do Seridó villages, Rio Grande do Norte State

higher-grade part of this metamorphism one observes reduced amounts of this mineral, but the few crystals present are well developed and practically no pleochroism is observed.

Muscovite Frequently in well developed flakes, muscovite is found practically in all assemblage in pelitic rocks.

Biotite This mineral has a widespread occurrence and is the principal mica in the pelitic metamorphosed rocks of the Serido Formation. The flakes are strongly pleochroic from yellow to reddish brown. When cordierite is present phlogopite is found in place of biotite. 
Figure 4 - Poikiloblastic texture in biotite-staurolite-schist. Thin-section observed in plane light. Road Acari-Cruzeta villages, Rio Grande do Norte State

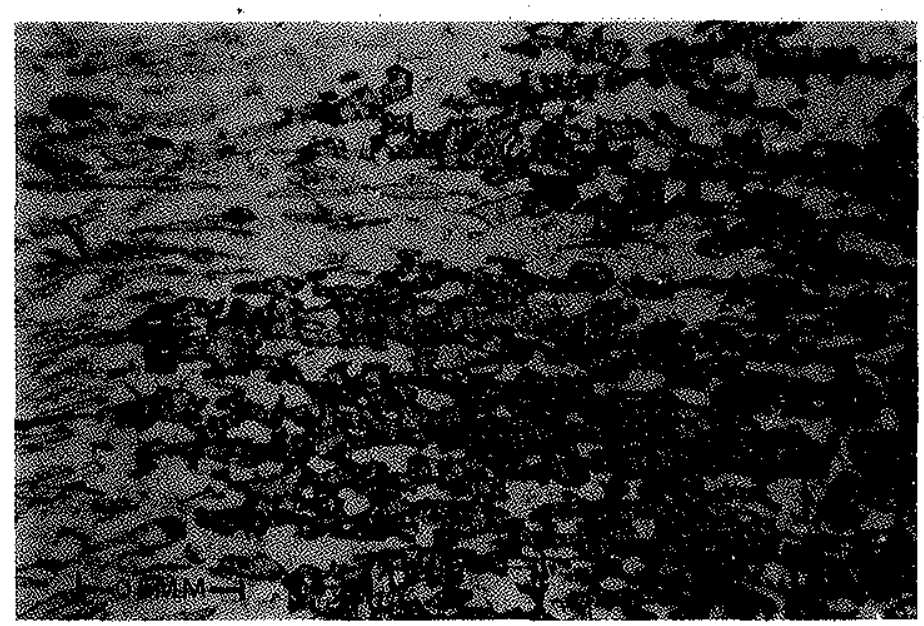

Garnet Garnet megacrysts are found in lower and higher-grade assemblages. The crystals generally show well developed forms.

Table II - Refractive index and specific gravity of garnets

\begin{tabular}{cccc}
\hline Sample 1 & Sample 2 & Sample 3 & Sample 4 \\
N 1.796 & N 1.800 & N 1.820 & N 1.810 \\
G 3.99 & G 4.05 & G 4.32 & G 4.08 \\
\hline
\end{tabular}

Sample $1(13.9 \mathrm{~km}$ from Acari village. Road Acari-Cruzeta; in phyllite); Sample 2 (Jardim do Seridó village); Sample 3 (Parelhas village); Sample 4 (Picuí village)

Staurolite This mineral is considered by Atherton (1965) as an index mineral of type a, of non-variable composition and limited occurrence due to host-rock composition and its small stability range. Atherton (op. cit.) calls attention to the number of reactions which

Figure 5 - Metacrysts formed by andalusite (A) and cordierite $(\mathrm{C})$ in biotite-andalusite-cordierite-schist. Logradouro, Acari village, Rio Grande do Norte State. ( $x$ nicols)

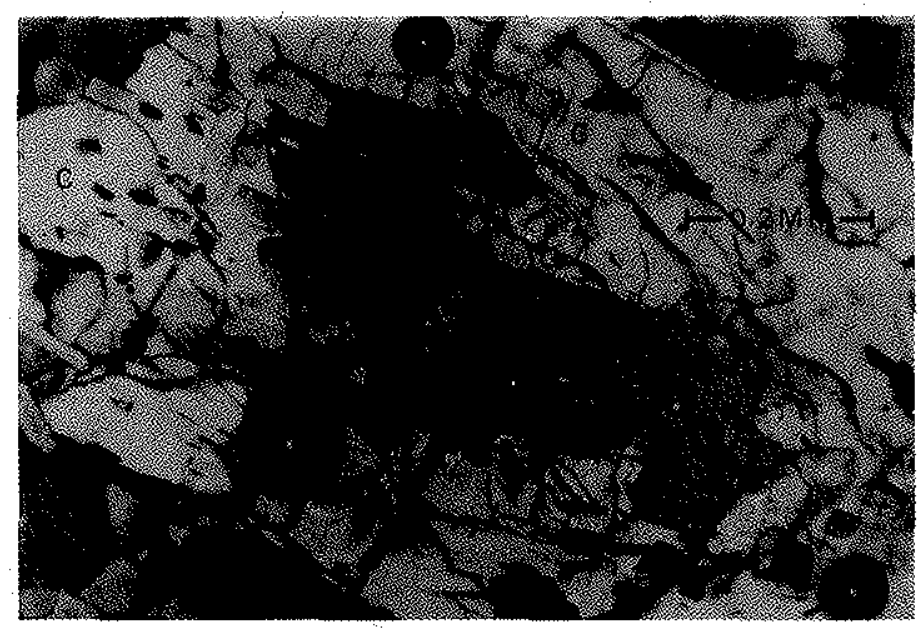




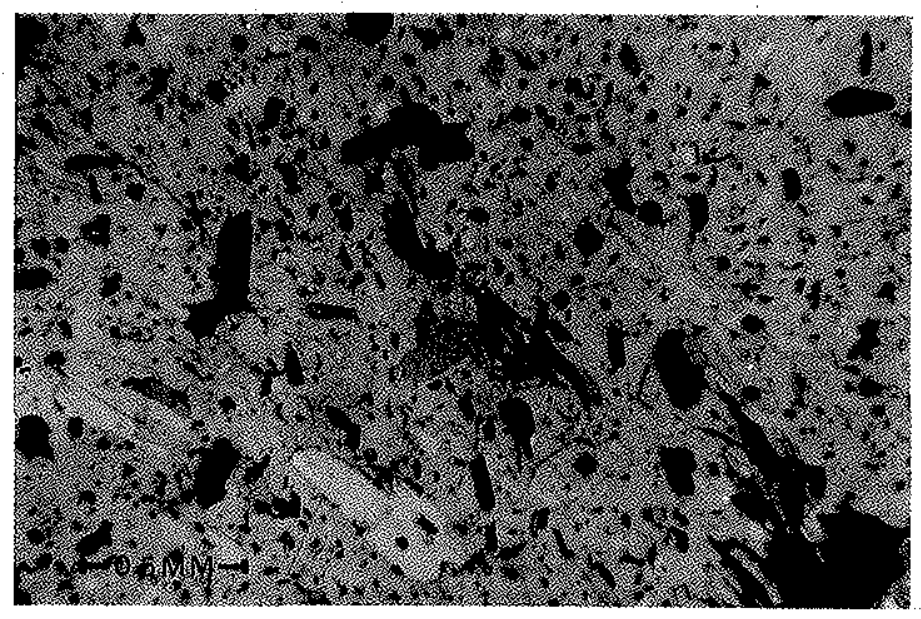

Figure 6 - Cordierite showing poikilitic texture, in cordierite-fels. Parelhas village, Rio Grande do Norte State. ( $\times$ nicols)

have been put forward for the genesis of staurolite. In the Serido region staurolite usually in porphyroblasts is present in assemblages with biotite, garnet and/or cordierite. In these staurolite assemblages textural evidence shows that staurolite is pseudomorphous after biotite.

The assemblage staurolite-andalusite-cordierite common in other types of metamorphism similar to Serido (low pressure types) is not found yet. In this type of metamorphism staurolite is limited by the appearence of andalusite and starts to crystallize at the beginning of the cordierite-amphibolite facies.

Andalusite It occurs commonly in porphyroblasts with a poikiloblastic texture. Its presence is noted only in thin-section. Microscopically the mineral is colorless and appears in assemblages with cordierite and cordierite plus sillimanite. It shows more intimate relations with cordierite than sillimanite (see Figs. 5 and 7).

Sillimanite This mineral appears in two distinct habits: in aggregates of needles not regularly arranged (showing a flamboyant radial aggregate of fibrolitic sillimanite and in moderate well-formed small crystals (Fig. 7). The textural examination shows that

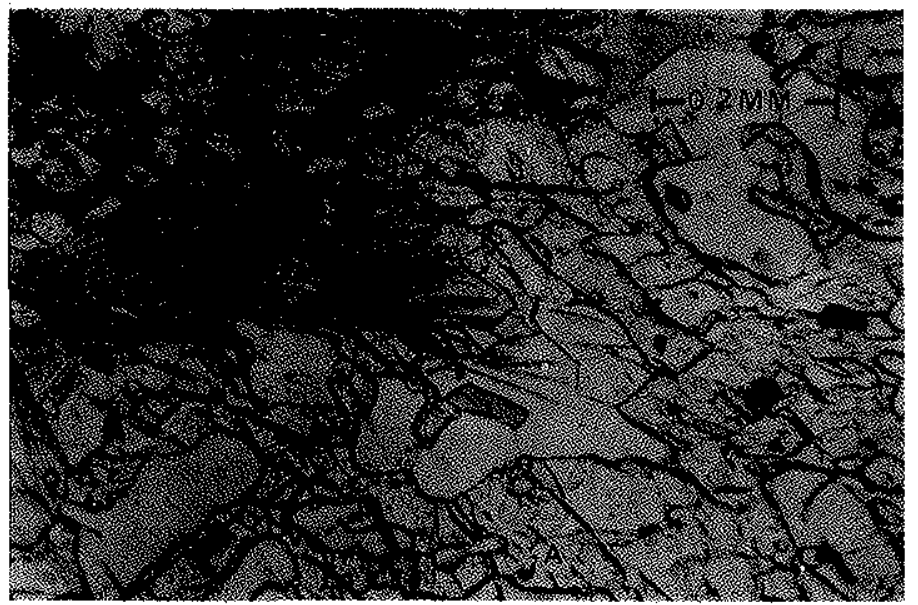

Figure 7 - Crystals of sillimanite (S) and fibrolite occurring together with andalusite (A). Thin-section observed in plane light 
this aluminium silicate does not grow directly from andalusite but appears to be grown solely after biotite.

The presence of andalusite and sillimanite is largely discussed by Pitcher (1965). In the particular case of the Seridó belt the overlap of the zones of andalusite and sillimanite is not the general case. Frequently in the higher-grade assemblage sillimanite is the only polymorph of aluminium silicate present, and again the mineral grows at the expense of the biotite. Naggar and Atherton (1970) consider that the presence of andalusite and sillimanite in the same rock is due to the metastable persistence of the lower temperature form.

Cordierite In the Seridó belt cordierite is the most abundant, principal and widespread metamorphic mineral of pelitic rocks in the cordierite-amphibolite facies (Fig. 6).

It occurs in porphyroblasts of different sizes alone or in assemblages with staurolite, andalusite and andalusite-sillimanite. Its occurrence in the Seridó-type region is as an index mineral of middle- and high-grade in metamorphosed pelitic rocks believed to have been formed at a certain depth in the earth's crust. The high-pressure equivalent to the cordieritengranulite assemblage (Newton, 1972) was not observed.

The general aspect of this mineral is as poikilitic crystals contributing to the gross texture of the rock. Partially altered cordierite shows two types of alteration. The one is very similar to that observed in the Front Range, Colorado, by Gable et.al. (1970), a yellow, apparently isotropic mineral, considered to be a late stage alteration product, possibly hydrothermal in origin. Qualitative analysis done by Gable et al. (op. cit.) reveals high aluminium and low iron and magnesium. Pinite is the other product of alteration.

Quartz and Plagioclase They are the principal clastic minerals found in all types of the metamorphosed pelitic rocks.

Accessory minerals . Tourmaline and apatite are practically the only found accessory minerals of phyllites and schists in the Seridó belt.

STRATIGRAPHY As was shown in the geologic setting of this paper there are many stratigraphic schemes applied to the investigated area.

It is important to note that the great majority of the previous works were based on structural analyses with petrological investigations considered as of secondary importance. This is for example the method followed by Ebert $(1969$, p. 8).

This work is the first one to involve the petrological aspects and their significance in the Seridó region. From this point of view some considerations are to be reviewed:

a) The name "Ceará Series" is not well applied to this region. In this point the authors agree with Suszczinski (1966) who suggests the name "Rio Grande do Norte Series".

b) Considering the metamorphic gradient for the first time observed in this area and the initial sediments considered as belonging to the "Seridó belt", we advocate the stratigraphical scheme of Tab. III.

The Serido metamorphic belt The Seridó orogenic belt is now intracontinental and characterized by the presence of only one facies series. Another feature of this metamorphic belt is the existence of numerous bodies of granitoid and granite masses of rocks sometimes associated with small occurrences of basic rocks (the more important being those associated with the Totoró masses) sporadically with development of a contact aureole. 
Table III - Stratigraphy in Seridó belt

\begin{tabular}{llll}
\hline Seridó series & Initial sediments & Greenschist facies & $\begin{array}{c}\text { Cordierite-amphibolite } \\
\text { facies }\end{array}$ \\
\hline $\begin{array}{c}\text { Seridó Formation } \\
\text { (upper clastic sequence) }\end{array}$ & $\begin{array}{l}\text { pelitic, frequently with } \\
\text { high aluminium-magnesium } \\
\text { content, exceptionally } \\
\text { with marl intercalations }\end{array}$ & phyllites, schists & $\begin{array}{l}\text { schists and fels } \\
\text { tactites }\end{array}$ \\
$\begin{array}{l}\text { Quixaba Formation } \\
\text { (intermediate sequence } \\
\text { of precipitation) }\end{array}$ & limestones and/or marls & - & $\begin{array}{l}\text { crystalline limestones } \\
\text { and tactites }\end{array}$ \\
$\begin{array}{c}\text { Equador Formation } \\
\text { (lower clastic sequence) }\end{array}$ & $\begin{array}{l}\text { pure or micaceous sand- } \\
\text { stones, sometimes } \\
\text { arkosic, conglomerates }\end{array}$ & - & $\begin{array}{l}\text { quartzites, micaceous } \\
\text { quartzites, meta- } \\
\text { conglomerates }\end{array}$ \\
\hline
\end{tabular}

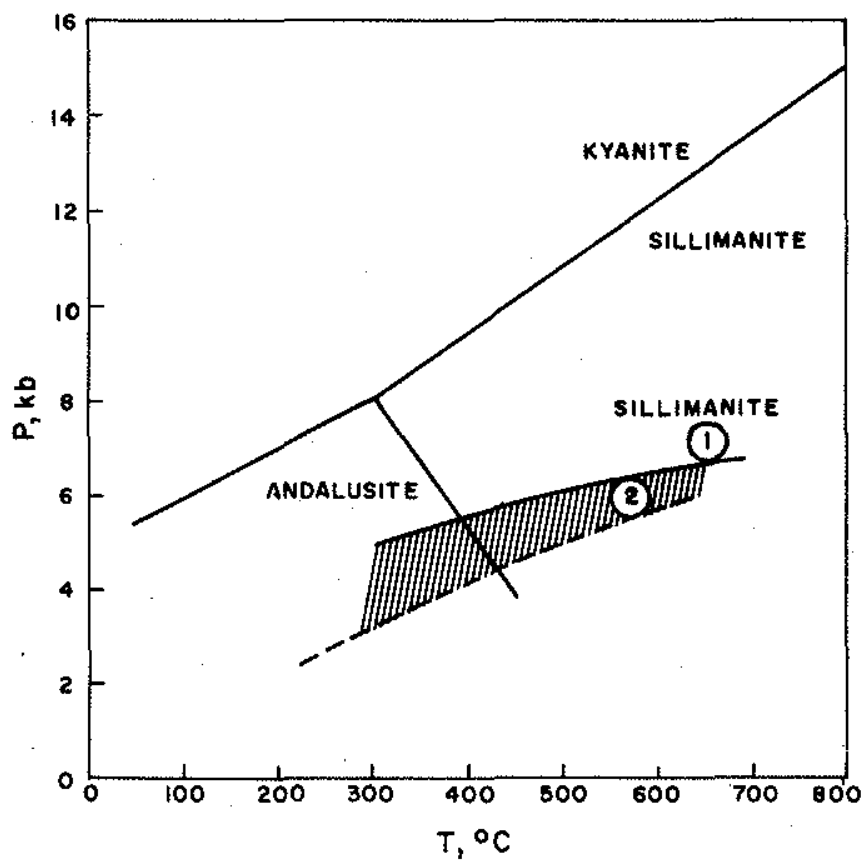

Figure 8 - Position of the low pressure facies series in relation to $\mathrm{P}$ and $\mathrm{T}$, showing the area in which the Serido type is expected to be developed. (1) Miyashiro's gradient for the Abukuma type; (2) Turner's adjustment for this type of metamorphism. Adapted from Turner $(1968$, p. 357)

The location of the Serido belt (Fig. 8) in the "low facies series type" was possible because there exists a progressive metamorphic sequence from greenschist to amphibolite facies.

THE GEOSYNCLINAL ORGANIZATION PATTERN IN SERIDO BELT The Seridó belt is a linear element with an eu-miogeosyncline couple in a northeast regional trend. The total extent of this element is unknown because its northern part is covered by the sediments of the Potiguar basin and the southern part is situated in a very complicated zone of granitic rocks influenced by the Patos lineament (Kegel, 1965).

The metamorphic rocks of the belt were derived mostly from pelitic and psammitic sediments and in a lesser amount from limestone and/or marls. 
Based on field and metamorphic studies the authors agree with Siqueira and Maranhão (1971) that the zonal pattern is characterized by the presence of eu-miogeosyncline furrows separated by a miogeanticline ridge but with the couple in reverse position.

The miogeosynclinal zone is characterized by pelitic rocks metamorphosed under the greenschist facies conditions (phyllites and schists) and by lower grade schists of the cordierite-amphibolite facies.

The eugeosyncline sequence is composed of: pure or micaceous quartzites sometimes arkosic, locally replaced by metamorphosed conglomerates; crystalline limestone and/or tactite, and schists frequently carrying metamorphic minerals (andalusite, sillimanite and cordierite - the latter being the most common and widespread).

The metamorphic area was divided into two progressive metamorphic facies groups which correspond approximately to the mio-eugeosyncline couple respectively. The metam morphism in the miogeosyncline furrow is mainly in the greenschist facies and that in eugeosyncline furrow in the cordieritemamphibolite facies (see Fig. 9).

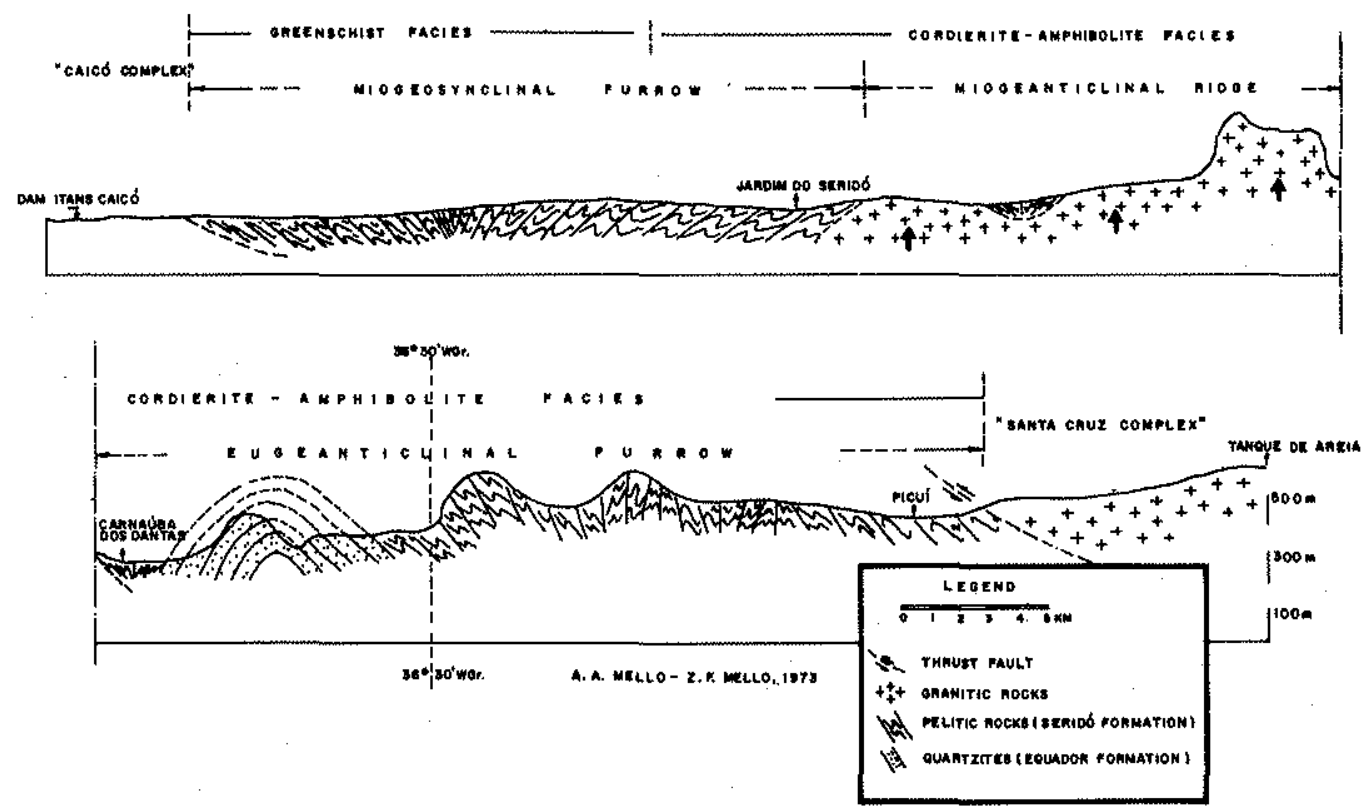

Figure 9 - Diagrammatic cross section in the Serido metamorphic belt

The miogeanticlinal ridge (Acarí ridge) is considered by Mello (1972) a granitoid of rheomorphic type. It is probable that this ridge belongs to sialic basement intruded synkinematically into the metamorphosed pelitic rocks ot the belt.

In the studied area no ophiolitic bodies were observed in the eugeosyncline furrow. The magmatic activity in this zone is related to a series of granitic intrusions of pegmatitic nature.

In summary, the geosynclinal organization pattern is in agreement with Aubouin (1965) in the following aspects.

1. The primary unit in the geosyncline is the eu-miogeosyncline couple.

2. The miogeosynclinal furrow, the miogeanticlinal ridge, the eugeosynclinal furrow, and the eugeanticlinal ridge are encountered in this succession. 
3. The metamorphism becomes less intense from the internal to external zones (metamorphic gradient).

4. The igneous activity is confined to the eugeosynclinal zone - in the particular case of the Serido geosyncline this activity is related to a series of granitic intrusions of pegmatitic character frequently showing mineralizations.

5. The internal eugeosynclinal and eugeanticlinal zones have a more or less typical geosynclinal structure.

AGE OF OROGENY AND REGIONAL METAMORPHISM IN SERIDO BELT The Seridó belt is situated in the Caririan Orogenic Area (Almeida et al., 1968), considered to have an absolute age of $470-520 \mathrm{~m} . \mathrm{y}$. determined by a group of samples. The cited author's sample $n .^{\circ} 26$ belonging to the granitoid of Acarí, considered in this work as syntectonic and as a miogeanticlinal ridge, has a $\mathrm{K}$-Ar age of $525 \pm 16 \mathrm{~m} . \mathrm{y}$.

Pflug (1967) in his work about the Brazilian shield considered the area as Precambrian.

Based on radiometric data the orogenic movements and metamorphism related to the Serido belt took place during the Precambrian. It is also probable that the events considered took place in the central part of a sialic basement (Caicó complex?) relatively thick and strong so as to permit shallow down - buckles in which metamorphism of the "low-pressure type" was developed, in accordance with Miyashiro's working hypothesis (Miyashiro, 1961).

SUMMARY AND CONCLUSIONS The above mentioned considerations permit us to establish for the Serido belt the following probable organization and elements.

1. Sediments of the "Ceará Series" now proposed to be called "Seridó Series" were deformed and metamorphosed during the Precambrian.

2. The regional metamorphism belongs to the low-pressure type and comprises rocks formed under the conditions of greenschist and cordierite-amphibolite facies.

3. The metamorphic gradient increases from west to east so that the rocks of the Santa Gruz quadrangle seem to be more related to Serido belt than those of the Caicó quadrangle.

4. The synkinematic phase of the batholitic intrusions was succeeded by a late and a postkinematic phase in which took place the emplacement of numerous mineralized bodies of pegmatites common in the higher grade part of the area.

5. The rocks belonging to the greenschist facies are present only in the western part of the belt and are represented principally by phyllites.

6. The granitic rocks of the belt are more or less continuous and in the northern part they are in association with migmatitic granite.

7. The quartzites are also more or less continuous and situated in the eugeosynclinal furrow, sometimes in association with crystalline limestones and/or tactites.

8. All the rocks have linear and planar elements in a northeasterly direction in accordance with regional trends in the belt and a zonal distribution with metamorphic gradient increasing from west to east. series.

9. The presence or absence of staurolite is not useful in determining the type of facies

10. Cordierite is the most important and characteristic metamorphic mineral of this belt.

Acknowledgments The authors are deeply indebted to the Conselho Nacional de Pesquisas (CNPq) and the Universidade de Pernambuco for financial support. Also appreciated are the careful reading made by Dr. J. M. Mabesoone, who reviewed the English text for publication. 


\section{REFERENCES}

ALMEIDA, F. F. M. de - 1967 - Origem e cvolução da plataforma brasileira. Div. Geol. Min., DNPM, Bol. 241: 36 pp.

ALMEIDA, F. F. M. de, MELGHER, G. G, CORDANI, U. G., KAWASHITA, K. and VANDOROS, P. - 1968 - Radiometric age determination from Northern Brazil. Soc. Bras. Geol, 17 (1): 3-14

ATHERTON, M. P. - 1965 - The chemical significance of isograds. In: Controls of Metamorphism, pp. 169-202. Ed. W. S. Pitcher and G. W. Flinn, Oliver and Boyd, Edinburgh

AUBOUIN, J. - 1965 - Geosynclines. Elsevier Publishing Company, Amsterdam

CHAVES, O. P. - 1947 - Cobre em Pedra Branca, Paraíba. Div. Fom. Prod. Min., DNPM, Bol. $81: 17-49$

CORDANI, U. G., MELCHER, G. G. and ALMEIDA, F.F.M. de - 1967 - In: CORDANI, U. G. - 1968 - Esboço da Geocronologia Pré-Cambriana da América do Sul. An. Acad. Brasil. Giênc., 40 (suplemento): 48-51

CRANDALL, R. - 1910 - Geografia, geologia, suprimento d'água, transporte e sondagens nos Estados orientais do Nordeste do Brasil. Ceará, Rio Grande do Norte, Parába. Public. Inspect. Obras contra as Secas, 4: $131 \mathrm{pp}$.

EBERT, H. - 1969 - Geologia do Alto Seridó. Div. Geol., Sudene, 11: $117 \mathrm{pp}$.

EBERT, H. - 1970 - The Precambrian geology of the "Borborema" Belt (States of Paraíba and Rio Grande do Norte; northeastern Brazil) and the origin of its mineral provinces. Geol. Rundschau, 59 (3): $1292-1326$

GABLE, D. J., SIMS, P. K. and WEIBLEN, P. W. - 1970 - Thermal metamorphism of cordierite-garnet-biotite gneiss, Front Range, Colorado. J. Geol, 75: 187-214

GANGULY, J. - 1972 - Staurolite stability an' related parageneses: theory, experiments, and applications. J. Petrol., 12: 149-175

HIETANEN, A. - $1967-$ On the facies series in various types of metamorphism. J. Geol., 75 : $187-214$

KEGEL, W. - 1965 - A estrutura geologica do Nordeste do Brasil. Div. Geol. Min., DNPM, Bol. 227: 47 pp.

MEDEIROS FERREIRA, J. A. - 1967 - Consideraçô obre uma nova estratigrafia do Seridó. Eng. Min. Metalurgia, XLV (265): 25-28

MELLO, A. A. and MELLO, Z. F. - 1971 - is sire de läcies metamórfica tipo andaluzita-sillimanita no Alto Serido. Rev. Assoc. Geol. Pernambuco, 3: 5-7

MELLO, A. A. - 1972 - O granitóide de Acari, RN. Rev. Assoc. Geol. Pernambuco, 5: 43-59

MELLO, Z. F, and MELLO, A. A. - 1972 - Zoneamento metamórfico no Alto Serido, RN. XXVI Congr. Bras. Geol., Resumo Comunicações, p. 206

MEUNIER, A. R. - 1964 - Succession stratigraphique et passages latéraux dus au métamorphisme dans la série Ceará, Antécambrien du Nord-Est brésilien. G. R. Acad. Sc. Paris, t. 259 : 3796-3 799

MIYASHIRO, A. - 1961 - Evolution of metamorphic belts. J. Petrol., 2: 277-311

MORAES, L. J. - 1924 - Serras c Montanhas do Nordeste. Public. Inspect. Obras contra as secas, 58: 242 pp.

MORAES, L. J. - 1938 - Cobre, estanho e outros minerais em Picuí e Soledade, Paraíba do Norte. Serv. Fom. Prod. Min., Bol. 28: 27 pp.

NAGGAR, M. H. and ATHERTON, M.P. - 1970 - The composition and metamorphic history of some aluminium silicate-bearing rocks from the aureoles of the Donegal granites. J. Petrol., 11: $549-589$

NEWTON, R. G. - 1972 - An experimental determination of the high-pressure stability limits of magnesian cordierite under wet and dry conditions. J. Geol., $80: 398-420$

PFLUG, R. - 1967 - Physikalische Altersbestimmungen aus dem Brasilianischen Schild. Tectonophysics, 5 (5): $381-411$

PITCHER, W. S. - 1965 - The aluminium silicate polimorphs. In: Controls of Metamorphism, pp. 327-341. Ed. W. S. Pitcher and G. W. Flinn. Oliver and Boyd, Edinburgh 
ROLFF, P. A. M. A. - 1945 - Contribuição ao estudo das jazidas de scheelita da Paraíba e do Rio Grande do Norte. Div. Fom. Prod. Min., DNPM, Bol. 63: 27 pp.

SIQUEIRA, L.P. and MARANHÃO, R. - 1971 - Novas consideraç̃̃es sobre a geologia da região do Seridó. Rev. Assoc. Geol. Pernambuco, 1: 41.45

SUSZCZINSKI, E. F. - 1966 - Consideraçðes sobre a evolução tectônica-orogenética da parte oriental do Escudo Brasileiro. Bol. Rec. Nat. Sudene, 4 (3/4): 371-416

TURNER, F.J. - 1968 - Metamorphic Petrology. McGraw-Hill, New York

WINKLER, H. G. F. - 1965 - Petrogenesis of Metamorphic Rocks. Springer-Verlag, Berlin 